\title{
Polarity of the cysJIH Operon of Salmonella typhimurium
}

\author{
By R. E. LOUGHLIN \\ Department of Biochemistry, University of Sydney, \\ New South Wales 2006, Australia
}

(Received 26 July 1974)

SUMMARY

Certain point and deletion mutants with lesions in the cysJ gene of Salmonella typhimurium have low levels of enzymes coded by the cysI and cys $H$ genes. These results support the hypothesis that an operon exists comprising genes $c y s J, I$ and $H$ which is transcribed in the direction from cysJ to $H$. The nearby cys $C$ and $c y s D$ genes do not form part of this cysJIH operon.

\section{INTRODUCTION}

In Salmonella typhimurium, the genes concerned with cysteine biosynthesis map at a number of widely separated regions of the linkage map (Sanderson, I972; Hulanicka, Kredich \& Treiman, 1974). One such region comprises a cluster of structural genes for the enzymes which convert sulphate to sulphide. Figure I shows the order of genes in this cluster (Mizobuchi, Demerec \& Gillespie, 1962). The enzymic activities of the products of genes cys $C, D$ and $H$ were established by Dreyfuss \& Monty (I963) and of genes cys $I$ and $J$ by Siegel \& Kamin (I97I) (see Fig. I). The orientation of the cluster with respect to nearby genes is thy $A \arg B$ cysC( $D H I) J$ (Jones-Mortimer, 1973).

It is postulated that genes cys $J, I$ and $H$ form an operon with a promoter at the cys $J$ gene end. Results which support this hypothesis are presented. Some of these results have been the subject of a preliminary report (Loughlin, 1974).

\section{METHODS}

Organisms. The prototrophic strain S. typhimurium LT2 and cysteine auxotrophs of Salmonella typhimurium were obtained from K. E. Sanderson or the late M. Demerec and have been described previously (Mizobuchi et al. 1962; Demerec, Gillespie \& Mizobuchi, I963). The salmonella phage P22 was obtained from B. W. Holloway.

Chemicals. Glutathione, NADPH, NADP, glucose 6-phosphate, FAD, glucose 6-phosphate dehydrogenase (yeast) and $N$-methyl- $N^{\prime}$-nitro- $N$-nitrosoguanidine (NTG) were obtained from Sigma, and cytochrome $c$ (equine heart) from Calbiochem. ATP and methyl viologen were purchased from $\mathrm{BDH}$, and $N, N$-dimethyl-p-phenylenediamine sulphate from Carlo Erba, Milan, Italy.

Media. Media used were: storage agar (Hartman, Loper \& Šrman, I960), cysteine nutrient agar ( $0.8 \%$ Bacto nutrient broth, Difco; $0.2 \mathrm{~mm}-\mathrm{L}$-cysteine. $\mathrm{HCl} ; \mathrm{I} \cdot 2 \%$ agar), and L broth (Lennox, I955). The liquid minimal medium used was medium $\mathrm{E}$ (Vogel \& Bonner, 1956), modified by the replacement of $\mathrm{MgSO}_{4}$ by $\mathrm{MgCl}_{2}$ and supplemented with glutathione (0.2 mM) and glucose $(0.25 \%)$. Solid minimal medium was that of Davis \& Mingioli 


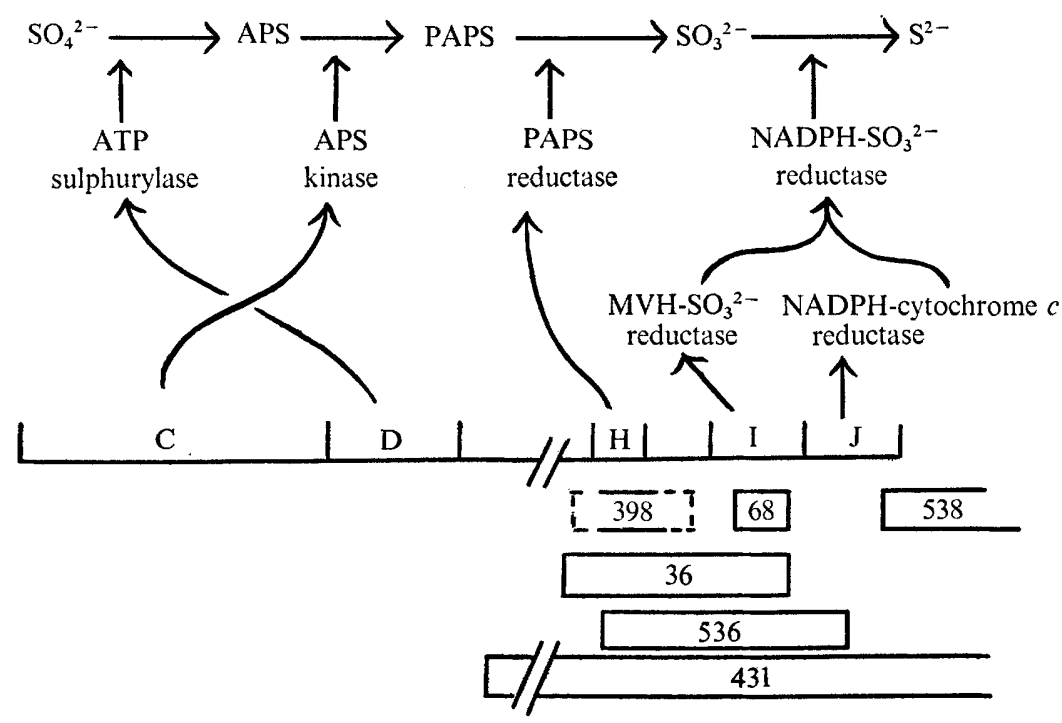

Fig. I. The sulphur branch of the pathway of cysteine biosynthesis in S. typhimurium: the pathway of conversion of sulphate to sulphide and the relationship of the enzymes concerned to the cluster of structural genes. APS, adenylylsulphate; PAPS, 3'-phosphoadenylylsulphate; MVH, reduced methyl viologen; ATP sulphurylase, ATP: sulphate adenylyl transferase (EC.2.7.7.5); APS kinase, ATP: adenylylsulphate $3^{\prime}$-phosphotransferase (EC.2.7.1.25); PAPS reductase, NADPH: PAPS oxidoreductase. The lesions in the deletion mutants are indicated by rectangles below the linkage map (after Demerec et al. 1963). The dotted parts of these rectangles may or may not be deleted.

(1950), similarly modified by the replacement of sulphate salts and supplemented with glucose $(0.2 \%)$ and either cystine $\left(0.42 \mathrm{~mm}\right.$, Kredich, I97I) or $\mathrm{Na}_{2} \mathrm{SO}_{4}(8.5 \mathrm{~mm})$.

Transduction. Recipient cultures were grown in L broth by shaking overnight at $37^{\circ} \mathrm{C}$. The cultures were centrifuged and resuspended in one-tenth vol. of T2 buffer (Hershey \& Chase, 1952). L broth lysates of P22 were diluted with T2 buffer and adsorption mixtures prepared from $0.1 \mathrm{ml}$ resuspended cells and $0.9 \mathrm{ml}$ diluted phage suspension to give a multiplicity of about 5 . After allowing each mixture to adsorb at $37^{\circ} \mathrm{C}$ for $5 \mathrm{~min}$, five selection plates were each spread with $0.1 \mathrm{ml}$.

Growth and disruption of bacteria. Colonies on cysteine nutrient agar were inoculated into $2 \mathrm{ml}$ of $\mathrm{L}$ broth and grown with shaking at $37^{\circ} \mathrm{C}$. Cultures were grown and cells disrupted by method A or B below.

Method A. L broth ( $10 \mathrm{ml}$ ) was inoculated with $0.5 \mathrm{ml}$ of an overnight $\mathrm{L}$ broth culture and shaken for $7 \mathrm{~h}$ at $37{ }^{\circ} \mathrm{C}$. A $5 \mathrm{ml}$ portion of this culture was used to inoculate $75 \mathrm{ml}$ of minimal medium and growth was continued immediately on a rotary shaker overnight at $37^{\circ} \mathrm{C}$. This culture was then added to $\mathrm{I} \cdot 42 \mathrm{l}$ of minimal medium and grown with aeration at $37^{\circ} \mathrm{C}$. Growth was followed by measuring the turbidity of a I to io dilution in $0.9 \% \mathrm{NaCl}$ at $600 \mathrm{~nm}$ in a Unicam SP 600 spectrophotometer. Cells from about $\mathrm{I} \cdot 21$ of culture were harvested in late log phase and the cell pastes frozen overnight. Frozen cells were disrupted in a modified Hughes press and the preparations mixed with $0 \cdot \mathbf{I}$ M-potassium phosphate buffer $\mathrm{pH} 7.7$ containing I mM-EDTA $(2.7 \mathrm{ml} / \mathrm{g}$ wet wt cell paste).

Method B. Minimal medium ( $10 \mathrm{ml}$ ) was inoculated with $0.5 \mathrm{ml}$ of an overnight $\mathrm{L}$ broth culture and shaken overnight at $37^{\circ} \mathrm{C}$. This culture was then added to $150 \mathrm{ml}$ of minimal 
medium in a I 1 flask and shaken on a rotary shaker at $37^{\circ} \mathrm{C}$. Turbidity was followed as in method A. Cells were harvested in late $\log$ phase and resuspended in $3 \mathrm{ml}$ of 0.1 M-potassium phosphate buffer $\mathrm{pH} 7 \cdot 7$ containing I mM-EDTA and stored at $4{ }^{\circ} \mathrm{C}$ overnight. Cells were disrupted using a Branson Model B-I 2 sonifier fitted with a micro tip.

In both methods, cultures with revertants greater than $0.01 \%$ of the population were rejected. Cell debris was removed by centrifugation at $28000 \mathrm{~g}$ for $40 \mathrm{~min}$ and the supernatants (crude extracts) were used for enzyme and protein assays.

Preparation of 3'-phosphoadenylyl sulphate (PAPS). A crude extract was prepared from three cultures of $S$. typhimurium cys 4439 by method A above. Four incubation mixtures, each with a final volume of $250 \mathrm{ml}$, contained per litre: Io mmol $\mathrm{MgCl}_{2}, 20 \mathrm{mmol} \mathrm{Na}_{2} \mathrm{SO}_{4}$, Io mmol sodium ATP $\mathrm{pH} \mathrm{7.3,} \mathrm{I00} \mathrm{mmol} \mathrm{tris-} \mathrm{HCl}$ buffer $\mathrm{pH} \mathrm{8.5}$, and $40 \mathrm{ml}$ of crude extract containing $825 \mathrm{mg}$ protein. The reaction in the first incubation mixture was commenced by the addition of extract $45 \mathrm{~min}$ before adding the remaining mixtures. Incubation was carried out at $37^{\circ} \mathrm{C}$ and $0.5 \mathrm{ml}$ samples were transferred from the first mixture to centrifuge tubes at $30 \mathrm{~min}$ intervals. After immersing these tubes in a boiling water bath for 2 min, cooling in ice and centrifuging in the cold, the supernatants were assayed for PAPS (see below) to determine the duration of the incubation. The reaction in the main incubation vessels was stopped after about $4 \mathrm{~h}$ by cooling in an ice bath and adding cold 2 M-perchloric acid $\left(37.5 \mathrm{ml} /\right.$ vessel). Subsequent operations were performed at $4{ }^{\circ} \mathrm{C}$. After standing for a short time, the material was centrifuged at $10000 \mathrm{~g}$ for $10 \mathrm{~min}$. The supernatant was adjusted to $\mathrm{pH} 7 \cdot 7$ with $5 \mathrm{M}-\mathrm{KOH}$ and then allowed to stand for $20 \mathrm{~min}$ before filtering through Whatman No. I paper. The filtrate was diluted with 5 vol. $\mathrm{H}_{2} \mathrm{O}$ and applied to a $58 \mathrm{~cm} \times 5.5 \mathrm{~cm}^{2}$ column of Bio-Rad AGIX4, 200 to $400 \mathrm{mesh}$, at an average flow rate of $315 \mathrm{ml} / \mathrm{h}$. After application of $200 \mathrm{ml} \mathrm{H}_{2} \mathrm{O}$, a linear gradient $(2 \cdot 0 \mathrm{l}, 0$ to I $\cdot 0 \mathrm{M}-\mathrm{NaCl})$ was applied at a flow rate of $\mathrm{I} 00 \mathrm{ml} / \mathrm{h}$ followed by $\mathrm{I} \cdot \mathrm{O}-\mathrm{NaCl}$. The fractions containing PAPS were mixed with $50 \mathrm{~g}$ of acid-washed Nuchar $\mathrm{C}-\mathrm{N}$ charcoal overnight. The charcoal was separated by filtration on Whatman No. I paper, washed with water and the PAPS eluted by stirring with two successive lots $(350 \mathrm{ml})$ of ethanol- $\mathrm{H}_{2} \mathrm{O}-\mathrm{NH}_{4} \mathrm{OH}$ (I2:I2:I, by vol.). These eluates were combined and evaporated nearly to dryness using a rotary evaporator and a $45^{\circ} \mathrm{C}$ bath. The damp residue was dissolved in $6 \mathrm{ml} 0.05 \mathrm{M}$-tris- $\mathrm{HCl}$ buffer $\mathrm{pH} 8.0$ and filtered through various grades of Whatman filter paper and finally through a $0.45 \mu \mathrm{m}$ Millipore filter. The orange filtrate was adjusted to $\mathrm{pH} \mathrm{8.I} \mathrm{using} \mathrm{I} \mathrm{M-tris-} \mathrm{HCl}$ buffer $\mathrm{pH} 8.5$ and frozen in several tubes. The yield was $500 \mu \mathrm{mol}$ PAPS.

Assay of PAPS. Phenolsulphokinase was prepared from lamb liver by the method of Gregory \& Lipmann (I957) with the modification that ro mM-2-mercaptoethanol was included in the buffers. The preparation was stored frozen in small lots. Freshly thawed lots were used in the assay and any excess discarded. PAPS was assayed by the method of Robbins (1963) except that cysteine was replaced by freshly diluted 2-mercaptoethanol.

$N A D P H$-cytochrome $c$ reductase assay. This activity was followed spectrophotometrically at $20^{\circ} \mathrm{C}$ by measuring cytochrome $c$ reduction at $550 \cdot 5 \mathrm{~nm}$. Cuvettes contained (in a final volume of $1.0 \mathrm{ml}$ ): $0.1 \mathrm{ml}$ of $0.5 \mathrm{M}$-potassium phosphate buffer $\mathrm{pH} 7.7$ containing I mMEDTA, $0.2 \mathrm{~mm}$-NADPH, $0.023 \mathrm{~mm}$-cytochrome $c$, and up to $0 . \mathrm{I} \mathrm{ml}$ of extract diluted with $0 \cdot$ I M-potassium phosphate buffer $\mathrm{pH} 7 \cdot 7$ containing I mM-EDTA. Duplicates varied by no more than $\pm 8 \%$ from the mean value.

Reduced methyl viologen-sulphite reductase assay. Methyl viologen was reduced in the apparatus shown in Fig. 2. Commercial oxygen-free nitrogen was purified by bubbling through alkaline sodium dithionite containing anthroquinone-2-sulphonic acid (Vogel, I96I) and a solution of methyl viologen maintained in the reduced state by acid-washed 


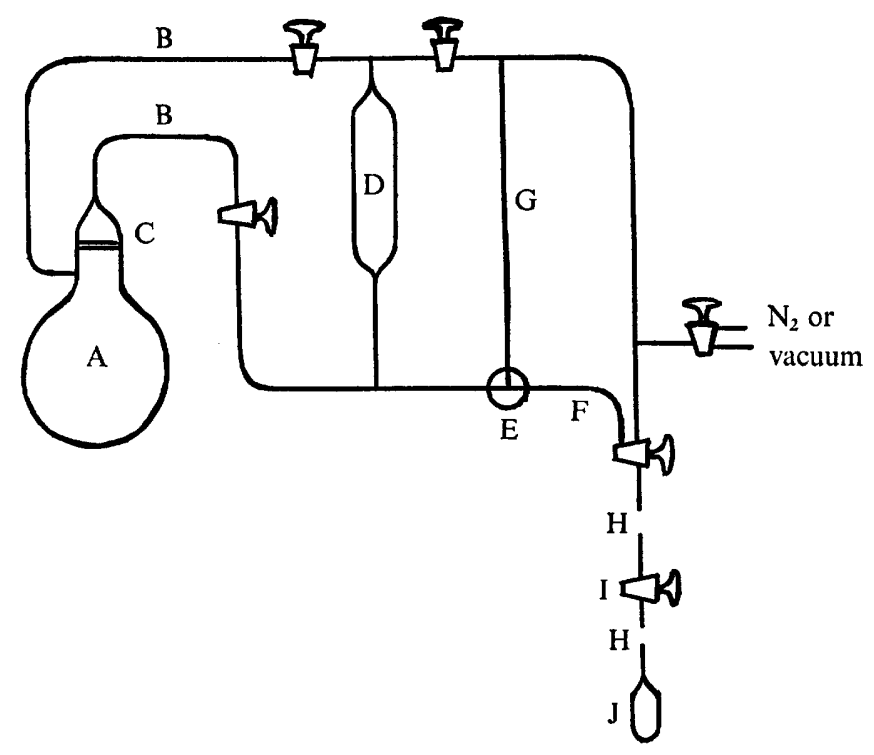

Fig. 2. Reduced methyl viologen apparatus. Methyl viologen is reduced with zinc (see Methods) in the reduction vessel $(A)$ which is connected to the remainder of the apparatus by polyvinyl chloride tubing (B). The MVH solution is passed through the sintered glass filter (C) to the reservoir (D) by inverting the reduction vessel. A sample of $\mathrm{MVH}$ solution is measured by passing through the $\mathrm{T}$ bore stopcock (E) to tube $F$ and the burette $G$. This sample is then transferred to the incubation tube (J) through the adaptor (I) which is connected to the vessel and apparatus by ground glass joints $(\mathbf{H})$.

zinc. A solution of methyl viologen was added to acid-washed granulated zinc in the reduction vessel and stirred. The apparatus was evacuated and refilled with purified $\mathrm{N}_{2}$ four times. After stirring the reduction vessel contents for $35 \mathrm{~min}$, the reduced methyl viologen (MVH) was transferred to the reservoir through the filter. After flushing the burette with the MVH solution, $\mathrm{MVH}$ was titrated by adding to $2 \mathrm{ml}$ of acidified $2 \mathrm{mM}-\mathrm{KMnO}_{4}$. The extent of reduction of the dye ranged from 60 to $80 \%$ between different batches. Incubation tubes containing extract, buffer and sulphite were connected, using adaptors, to the apparatus, evacuated twice and the MVH solution added. The stopcock on the adaptor was then closed, and the tubes incubated at $37^{\circ} \mathrm{C}$ for $15 \mathrm{~min}$ with the adaptor still attached. Incubation mixtures contained (in a final volume of $2.5 \mathrm{ml}$ ): extract diluted in 0.1 M-potassium phosphate buffer $\mathrm{pH} 7.7$ containing I mM-EDTA, $0.8 \mathrm{~mm}-\mathrm{Na}_{2} \mathrm{SO}_{3}$, and up to $2 \mathrm{ml}$ of the MVH solution. The reaction was stopped by oxidizing the MVH. The adaptor was replaced by a stopper and the oxygen thus admitted was used to oxidize the $\mathrm{MVH}$ by vortexing. Sulphide was determined by the method of Siegel (1965) with the following modifications: $0.2 \mathrm{ml}$ of the $N, N$-dimethyl-p-phenylene diamine reagent was added, followed immediately by the addition of $0.2 \mathrm{ml}$ of the ferric chloride reagent. After $20 \mathrm{~min}, 0.5 \mathrm{ml}$ ethanol was added and insoluble material removed by centrifuging at $28000 \mathrm{~g}$ for $20 \mathrm{~min}$. Variation of the MVH concentration showed that optimal sulphide production was obtained with $\mathrm{I} \cdot 5 \mathrm{ml}$ MVH solution ( $75 \%$ reduced) per tube, prepared from $20 \mathrm{~mm}$-methyl viologen. Addition of $2.0 \mathrm{ml} \mathrm{MVH}$ solution/tube gave $90 \%$ of the optimum value. At this level of MVH, sulphide production at low enzyme concentrations was up to $10 \%$ less than that expected from data obtained at high enzyme concentrations, assuming linearity. The addition of $10 \mu \mathrm{mol}$ of zinc acetate to the incubation mixtures inhibited sulphide production by $30 \%$. Since batches 
of MVH varied in their extents of reduction and probably their zinc concentrations, a wildtype extract was assayed with each batch of MVH. Each extract was assayed in duplicate at two protein concentrations. Standard deviations derived from these four values were less than $10 \%$ of the mean wild-type value and less than $3 \%$ of the mean wild-type value for extracts with less than $10 \%$ of the wild-type specific activity.

PAPS reductase assay (NADPH:PAPS oxidoreductase). The method used was that described by Kredich (I97I) with minor modifications. Incubation mixtures contained (in a final volume of $\mathrm{I} .5 \mathrm{ml}$ ) $: 0.2 \mathrm{ml} 0.5 \mathrm{M}$-potassium phosphate buffer $\mathrm{pH} 7.7$ containing I mMEDTA, $5 \mu \mathrm{mol}$ glucose 6-phosphate, $0 . \mathrm{I} \mu \mathrm{mol}$ NADP, $0 . \mathrm{I} 7$ units of glucose 6-phosphate dehydrogenase, $15 \mathrm{nmol}$ FAD, $5.5 \mu \mathrm{g}$ highly purified sulphite reductase (from $S$. typhimurium LT2, $0.49 \mu \mathrm{mol}$ sulphide formed $/ \mathrm{mg}$ protein $/ \mathrm{min}$ ), crude extract containing 2 to $4 \mathrm{mg}$ of protein diluted into $0.5 \mathrm{ml}$ of $0 . \mathrm{I}$ M-potassium phosphate buffer $\mathrm{pH} 7.7$ containing I mM-EDTA, and $0.45 \mathrm{ml} 50$ mM-tris- $\mathrm{HCl}$ buffer $\mathrm{pH} 8.0$ containing $0.44 \mu \mathrm{mol}$ of PAPS. Incubation was carried out in stoppered tubes at $37^{\circ} \mathrm{C}$ for $15 \mathrm{~min}$. Sulphide was determined as described above for the MVH reductase assay, using $0.2 \mathrm{ml}$ of each reagent per tube. Each extract was assayed at two protein concentrations. Active extracts showed large differences, the higher protein concentration showing the higher specific activity. Thus the results are regarded as semi-quantitative even though duplicates varied by no more than $\pm 10 \%$ from the mean value.

Protein determination. The protein in crude extracts was determined by the method of Lowry, Rosebrough, Farr \& Randall (195I).

\section{RESULTS}

In preliminary experiments, an extract of the deletion mutant $c_{y s} J_{53} 8$ was found to have a very low level of MVH-sulphite reductase. To explain this result it was proposed that genes cys $J$ and $I$ form an operon in which the cys $J$ gene is transcribed before the cys $I$ gene. This implies the existence of a promoter at the right end of the cys $J$ gene as the map is drawn in Fig. I. This promoter would be missing in the deletion mutant cys $J_{53} 8$.

Extracts of the deletion mutant cys536 which would be predicted to have wild-type levels of NADPH-cytochrome $c$ reductase were found to have very low levels of this activity. The paper by Demerec et al. (I963) refers to this mutant in some places as $H_{536}$ and in other places as $\mathrm{HIJ}_{536}$. To clarify this situation, transduction experiments were performed which showed that deletion 536 could yield wild-type recombinants with some cysJ point mutants $\left(\right.$ cys $\left.J_{494}, J_{275}\right)$ but not others $\left(c y s J_{389}, J_{3} I 7\right)$. It is concluded that the deletion extends into the cysJ gene. This confirms the designation of 536 as $H_{I J} J_{53} 6$ in the records of the Salmonella Genetics Stock Centre (Sanderson, personal communication) and accounts for the low level of NADPH-cytochrome $c$ reductase activity in extracts of this mutant.

To determine whether the cys $H$ gene is part of the cys $J I$ operon, extracts of selected deletion mutants were assayed for PAPS reductase as well as MVH-sulphite and NADPH-cytochrome $c$ reductases. The results are shown in Table $\mathrm{I}$. The finding that deletion mutant cys $J 538$ also lacks PAPS reductase indicates that gene $c y s H$ is part of the $c y s J I$ operon. If the cys $J$ gene is the first gene in the cysJIH operon, nonsense mutants in the cys $J$ gene would be expected to have polar effects, namely lowered expression of the $c y s I$ and $H$ genes. To search for such polar mutants, extracts were prepared by method B (Methods) from nearly all of the available cysJ point mutants (Demerec et al. 1963) and assayed for MVH-sulphite reductase activity $(2 \cdot 0 \mathrm{ml}$ of $\mathrm{MVH}$ solution prepared from Io mM-methyl viologen was added to vessels containing enzyme diluted into $0.2 \mathrm{ml}$ of 0.1 M-potassium phosphate buffer $\mathrm{pH} 7 \cdot 7$ 
Table I. Relative enzyme levels in mutant extracts

Enzyme levels are expressed as a percentage of the specific activity of the wild-type extract.

\begin{tabular}{|c|c|c|c|}
\hline Extract & $\begin{array}{l}\text { PAPS } \\
\text { reductase }\end{array}$ & $\begin{array}{l}\text { MVH- } \\
\text { sulphite } \\
\text { reductase }\end{array}$ & $\begin{array}{l}\text { NADPH- } \\
\text { cytochrome } c \\
\text { reductase }\end{array}$ \\
\hline \multicolumn{4}{|l|}{ Wild-type } \\
\hline LT2 & 100 & 100 & 100 \\
\hline \multicolumn{4}{|c|}{ Deletion mutants } \\
\hline cysHI36 & I & 3 & 94 \\
\hline cys $I 68$ & 24 & I & 106 \\
\hline cys $\mathrm{H}_{398}$ & I & 140 & 104 \\
\hline cys $\mathrm{HIJ}_{536}$ & I & 2 & 3 \\
\hline cysJ 538 & I & I & 3 \\
\hline \multicolumn{4}{|c|}{ Selected cysJ mutants } \\
\hline cysJ 148 & 5 & 4 & \\
\hline cysJ223 & 3 & 2 & 3 \\
\hline cysJ $J_{304}$ & 9 & 6 & 3 \\
\hline cysJ630 & 4 & 4 & 3 \\
\hline
\end{tabular}

Extracts were prepared by method A (Methods). In the assays for MVH-sulphite reductase, $1.5 \mathrm{ml}$ of MVH solution prepared from $20 \mathrm{~mm}$-methyl viologen was added to vessels containing enzyme diluted into $0.5 \mathrm{ml} \mathrm{O.I} \mathrm{M-potassium} \mathrm{phosphate} \mathrm{buffer} \mathrm{pH} 7.7$ containing I mM-EDTA. Other details are given in Methods. The specific actitities of the LT2 extract (wild-type) used as a control for the deletion mutants were: PAPS reductase and MVH-sulphite reductase, 1.5 and $36 \mathrm{nmol}$ sulphide formed $/ \mathrm{mg}$ protein/min, respectively; NADH-cytochrome $c$ reductase, $570 \mathrm{nmol}$ cytochrome $c$ reduced $/ \mathrm{mg}$ protein $/ \mathrm{min}$. The specific activities of the LT2 extract used as a control for the selected cys $J$ mutant extracts were: PAPS reductase and MVHsulphite reductase, $1 \cdot 3$ and $23 \mathrm{nmol}$ sulphide/mg protein/min, respectively; NADPH-cytochrome $c$ reductase, $530 \mathrm{nmol}$ cytochrome $c$ reduced $/ \mathrm{mg}$ protein $/ \mathrm{min}$.

containing I mM-EDTA; other details are given in Methods). The extracts exhibited a wide range of activity from $0 \%$ to slightly more than $100 \%$ of the wild-type specific activity. CysJ point mutants having low levels of activity (between 0 and 10 \% of wild-type) were tested for revertibility by NTG (Berkowitz et al. I968). Those which could be reverted were selected for enzyme assays. Table I shows the enzyme levels of these selected cysJ point mutants. It is clear that all of these selected cysJ point mutants are polar, having very low levels of the cys $I$ and $H$ gene products.

\section{DISCUSSION}

The results of enzyme assays of extracts of the deletion mutant $\operatorname{cys}_{53} J_{3}$ and the selected cysJ point mutants (Table I) show that these mutants have polar effects. From the direction of these polar effects it is proposed that genes cys $J, I$ and $H$ form an operon which is transcribed from the $c y s J$ gene end. This implies the existence of a promoter near the commencement of the cysJ gene. Such a promoter would be missing from the deletion mutant $c_{5} J_{53} 8$, thus accounting for the observed polarity. The point mutants listed in Table I are polar and are revertible by NTG. It is thus probable that they are nonsense mutants. This would explain their polarity since in other operons nonsense mutants which map in the first gene of an operon can exhibit polarity (Beckwith, 1964; Brenner \& Beckwith, I965; Newton, Beckwith, Zipser \& Brenner, 1965).

That the operon is not transcribed in the direction from cys $H$ to $J$ is indicated by the results of assays of the deletion mutant cys HI36. Extracts of this mutant have high levels of NADPH-cytochrome $c$ reductase (Table I). This result is the one expected if polarity is from cysJ to cysH. The ditto deletion mutant cys43I (Demerec et al. 1963; Itikawa \& Demerec, 1967 ), like $J_{538}$, would be expected to lack the promoter for the cysJI operon (see 
Fig. 1). An extract of cys43I has been shown to possess ATP sulphurylase and APS kinase activities (Kredich, I97I). This indicates that genes cys $C$ and $D$ are not part of the cysJIH operon.

On mixing extracts of cys 168 with extracts of cysJ266, reconstitution of up to $50 \%$ of the wild-type NADPH-sulphite reductase activity has been observed (Siegel et al. 1971). By contrast, previous experiments, using extracts of cys 168 and $c y s J_{53} 8$, showed that less than $\mathrm{I} \%$ of the wild-type NADPH-sulphite reductase activity was formed (Henderson \& Loughlin, 1968). This difference can now be explained by the polarity exhibited in extracts of $c y s J 538$ which contain very low levels of MVH-sulphite reductase activity (I \%; Table I). In the survey of cysJ mutants (see Results) $c y s J 266$ was found to have $15 \%$ of the wild-type MVH-sulphite reductase activity. This level is probably sufficient to account for the results of mixing cysJ266 extracts with extracts of cysI68.

This work was supported by a University of Sydney research grant.

\section{REFERENCES}

BECKwITH, J. R. (1964). A deletion analysis of the lac operator region of Escherichia coli. Journal of Molecular Biology 8, 427-430.

Berkowitz, D., Hushon, J. M., Whitfield, H. J., Jun., Roth, J. \& Ames, B. N. (i968). Procedure for identifying nonsense mutations. Journal of Bacteriology 96, 21 5-220.

BRENNER, S. \& BeCKWITH, J. R. (1965). Ochre mutants, a new class of suppressible nonsense mutants. Journal of Molecular Biology r3, 629-637.

Davis, B. D. \& Mingioli, E. S. (1950). Mutants of Escherichia coli requiring methionine or vitamin $\mathrm{B}_{12}$. Journal of Bacteriology 6o, 17-28.

Demerec, M., GillesPIE, D. H. \& Mizobuchi, K. (1963). Genetic structure of the cysC region of the Salmonella genome. Genetics 48, 997-1009.

DREYFuss, J. \& MONTY, K. J. (I963). The biochemical characterization of cysteine-requiring mutants of Salmonella typhimurium. Journal of Biological Chemistry 238, 1019-1024.

Gregory, T. D. \& LipMANN, F. (1957). The transfer of sulfate among phenolic compounds with $3^{\prime}, 5^{\prime}$-diphosphoadenosine as coenzyme. Journal of Biological Chemistry 229, 108 I-1090.

Hartman, P. E., Loper, J. C. \& ŠERMAN, D. (I960). Fine structure mapping by complete transduction between histidine-requiring salmonella mutants. Journal of General Microbiology 22, 323-353.

Henderson, R. J. \& Loughlin, R. E. (1968). Complementation in vitro between cysteine auxotrophs of Salmonella typhimurium. Biochimica et biophysica acta 156, 195-197.

HersheY, A. D. \& ChASE, M. (1952). Independent functions of viral protein and nucleic acid in growth of bacteriophage. Journal of General Physiology 36, 39-56.

Hulanicka, M. D., Kredich, N. M. \& Treiman, D. M. (1974). The structural gene for $O$-acetylserine sulf hydrylase A in Salmonella typhimurium. Journal of Biological Chemistry 249, 867-872.

Itikawa, H. \& DemereC, M. (I967). Ditto deletions in the cysC region of the Salmonella chromosome. Genetics 55, 63-68.

JONES-MORTIMER, M. C. (1973). Mapping of structural genes for the enzymes of cysteine biosynthesis in Escherichia coli $\mathrm{KI} 2$ and Salmonella typhimurium LT2. Heredity 31, 21 3-221.

KreDich, N. M. (197I). Regulation of L-cysteine biosynthesis in Salmonella typhimurium. I. Effects of growth on varying sulfur sources and $O$-acetyl-L-serine on gene expression. Journal of Biological Chemistry 246, 3474-3484.

LenNox, E. S. (I955). Transduction of linked genetic characters of the host by bacteriophage PI. Virology I, 190-206.

LoughLIN, R. E. (1974). Regulation of reduced methyl viologen-linked sulphite reductase of Salmonella typhimurium. Proceedings of the Australian Biochemical Society 7 , I4.

Lowry, O. H., Rosebrough, N. J., Farr, A. L. \& Randall, R. J. (195I). Protein measurement with the Folin phenol reagent. Journal of Biological Chemistry 193, 265-275.

Mizobuchi, K., Demerec, M. \& Gillespie, D. H. (1962). Cysteine mutants of Salmonella typhimurium. Genetics $47,1617-1627$. 
Newton, W. A., Beckwith, J. R., Zipser, D. \& Brenner, S. (1965). Nonsense mutants and polarity in the lac operon of Escherichia coli. Journal of Molecular Biology 14, 290-296.

RoBBINs, P. W. (1963). Preparation and properties of sulfuryl adenylates. In Methods in Enzymology, vol. 6, pp. 773-775. Edited by S. P. Colowick \& N. O. Kaplan. New York and London: Academic Press.

SANDERSON, K. E. (1972). Linkage map of Salmonella typhimurium, edition IV. Bacteriological Reviews 36, $558-586$.

SIEGEL, L. M. (1965). A direct microdetermination for sulfide. Analytical Biochemistry Ir, 126-132.

Siegel, L. M. \& KAMIN, H. (I97I). TPNH-sulphite reductase (SiR) from E. coli and Salmonella typhimurium: subunit structure and gene assignment. Federation Proceedings 30, 126I (Abstract).

Siegel, L. M., Kamin, H., Rueger, D. C., Presswood, R. P. \& Gibson, Q. H. (I971). In Flavins and Flavoproteins, Proceedings of the Third International Symposium on Flavins and Flavoproteins, Durham, North Carolina, pp. 523-554. Edited by H. Kamin. London: Butterworths.

Vogel, A. I. (196I). A Text Book of Quantitative Inorganic Analysis Including Elementary Instrumental Analysis, 3rd edn, p. I08I. London: Longmans, Green.

VOGEL, H. J. \& BONNER, D. M. (1956). Acetylornithinase of Escherichia coli: partial purification and some properties. Journal of Biological Chemistry 218, 97-106. 